CZASOPISMO INŻYNIERII LĄDOWEJ, ŚRODOWISKA I ARCHITEKTURY JOURNAL OF CIVIL ENGINEERING, ENVIRONMENT AND ARCHITECTURE

JCEEA, t. XXXIII, z. 63 (3/16), lipiec-wrzesień 2016, s. 431-438

\author{
Katarzyna STANISZ ${ }^{1}$ \\ Stanisław GUMUŁA ${ }^{2}$
}

\title{
ENERGETYKA PROSUMENCKA W BUDOWNICTWIE ROZPROSZONYM
}

\begin{abstract}
Idea energetyki prosumenckiej polega na połączeniu dwóch procesów w jednym obiekcie. Procesu konsumpcji i procesu produkcji energii. Przez konsumpcję energii rozumiemy w tym przypadku wykorzystanie wyprodukowanej energii przez samego producenta i ewentualnie uzupełnienie swoich potrzeb energetycznych pobieraniem energii z krajowego systemu elektroenergetycznego. Przez produkcję energii rozumiemy tutaj wytwarzanie energii w ilości przekraczającej potrzeby własne w celu sprzedaży do krajowego systemu elektroenergetycznego. Na szczególne zainteresowanie producentów zasługują technologie oparte na surowcach odnawialnych, ponieważ cena odkupywania energii pochodzącej z tych źródeł jest znacznie wyższa niż energii pochodzącej z surowców kopalnych.

Przedstawiana praca zawiera charakterystyki technologii wytwarzania energii elektrycznej zarówno te już opracowane i dostępne oraz te które są na etapie badań z perspektywą na wdrożenie w bliżej nieokreślonej przyszłości.
\end{abstract}

Słowa kluczowe: rozproszone źródła energii, produkcja energii elektrycznej, współpraca producenta z krajowym systemem elektroenergetycznym

\section{Wprowadzenie}

Pozyskiwanie energii w skali całego świata opiera się aktualnie głównie na surowcach kopalnych i procesie spalania. Takie technologie pozyskiwania energii niosą ze sobą poważne zagrożenia: wyczerpywanie się kopalnych surowców energetycznych, zmiany klimatyczne, konflikty zbrojne których podłożem będzie dostęp do zasobów surowców energetycznych, ponieważ są bardzo nierównomiernie rozłożone na kuli ziemskiej. Ta sytuacja zmusza społeczność międzynarodową do pozyskiwania energii ze źródeł odnawialnych z pominięciem procesu spalania. Odnawialne źródła energii są z reguły źródłami rozproszonymi, to znaczy ich moc przypadająca na jednostkę powierzchni ziemi jest stosunkowo niewielka. Pociąga to za sobą konieczność rozproszenia również obiektów dokonujących zamiany

\footnotetext{
${ }^{1}$ Autor do korespondencji / corresponding author: Katarzyna Stanisz, Państwowa Wyższa Szkoła Zawodowa im. S. Pigonia w Krośnie, Zakład Budownictwa, ul. Dmochowskiego 12, 38-400 Krosno; katsta1304@interia.pl

${ }^{2}$ Stanisław Gumuła, AGH , Wydział Energetyki i Paliw, B-3, II p., pok. 202a; stangum@gmail.com
} 
surowców energetycznych na energię użyteczną. W ten sposób zrodziła się koncepcja energetyki prosumenckiej polegającej na tym, że konsumenci energii $\mathrm{z}$ natury rzeczy rozproszeni, będą równocześnie producentami energii.

\section{Technologie opracowane i dostępne}

\subsection{Fotowoltaiczna konwersja promieniowania Słońca}

Moc promieniowania Słońca na szczycie atmosfery ziemskiej wynosi około $1390 \mathrm{~W} / \mathrm{m}^{2}$. Na skutek odbicia, absorpcji i rozproszenia w zależności od pory dnia i roku, do powierzchni Ziemi dociera średnio tylko około $50 \%$ tej mocy. Promieniowanie które dociera do Ziemi pod określonym kątem składa się $\mathrm{z}$ promieniowania bezpośredniego, rozproszonego, a także z promieniowania odbitego od obiektu na powierzchni Ziemi. Promieniowanie bezpośrednie i rozproszone nosi nazwę promieniowania całkowitego i jest to wartość zmienna w zależności od pory roku oraz zachmurzenia (rys.1). Moc promieniowania słonecznego w Polsce charakteryzuje się bardzo nierównomiernym rozkładem w cyklu rocznym. Średnio $80 \%$ całkowitej energii słonecznej przypada na sześć miesięcy sezonu wiosenno- letniego, od początku kwietnia do końca września. I przy optymalnych warunkach pogodowych (bezchmurne niebo, środek dnia) wartość energii całkowitego promieniowania słonecznego na powierzchni Ziemi wynosi od 900 do $1200 \mathrm{kWh} / \mathrm{m}^{2} \cdot a$. Dla systemów solarnych szczególnie niekorzystne są warunki zimowe (rys.1), kiedy to ilość energii słonecznej przypadającej na jednostkę powierzchni jest najmniejsza [1].

Energia promieniowania słońca może być wykorzystywana w procesie konwersji fotowoltaicznej do produkcji energii elektrycznej. Urządzeniem, pozwalającym na bezpośrednią zamianę energii promieniowania słońca na energię elektryczną są fotoogniwa słoneczne (rys.3). Ogniwo fotowoltaiczne zbudowane jest $\mathrm{z}$ materiału półprzewodnikowego, w którym pod wpływem absorpcji promieniowania powstaje napięcie na zaciskach ogniwa. Istnieje wiele typów i odmian tych urządzeń, $w$ zależności od stosowanego materiału półprzewodnikowego (krzem, arsenku galu, siarczanu kadmu) oraz struktury tego materiału (monokryształy, polikryształy). Najpowszechniejszym materiałem używanym do produkcji ogniw jest krzem. Sprawność ogniw krzemowych wynosi około $18 \%$. Największe sprawności przetwarzania promieniowania słonecznego na energię elektryczną (do 30\%) uzyskuje się z ogniw wytworzonych z arsenu galu, siarczku kadmu czy też fosforku indu ale ogniwa te są znacznie droższe i stosowane przede wszystkim w technice kosmicznej [2]. Trzeba mieć jednak na uwadze, że podawana przez producenta moc jest wartością otrzymywaną $\mathrm{w}$ warunkach standardowych. Moc uzyskiwana w warunkach rzeczywistych jest zazwyczaj niższa od nominalnej. 


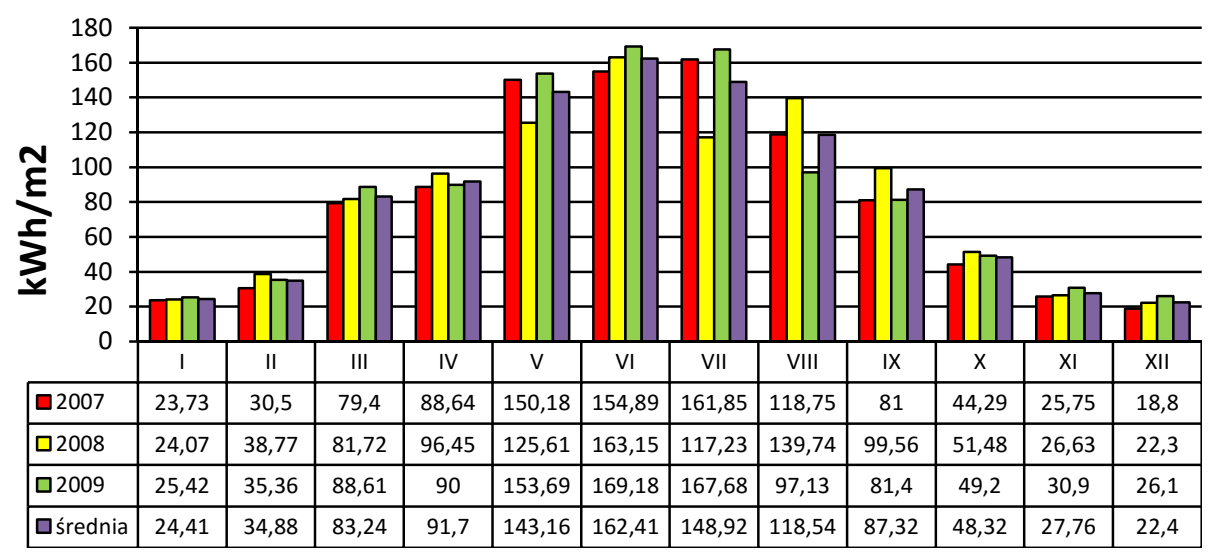

Rys.1. Energia promieniowania słonecznego w trzech kolejnych latach w tej samej miejscowości Podkarpacia [badania własne]

Fig.1. Solar energy for three consecutive years in the same place Podkarpacia [own research]

\subsection{Energia kinetyczna wiatru jako źródło energii elektrycznej}

Około 1-2 \% energii słonecznej docierającej do Ziemi zamienia się na energię wiatru. Oszacowanie lokalnego potencjału energetycznego wiatru jest podstawowym krokiem przy podejmowaniu wszelkich decyzji związanych z energetyką wiatrową. Komplikacje $\mathrm{z}$ oceną zasobów użytecznych wiatru wynikają z jego stochastycznej natury. Znajomość zasobów energii kinetycznej wiatru jest niezbędna do oszacowania rocznej produkcji energii elektrycznej z energii kinetycznej wiatru. Wstępna ocena zasobów energetycznych wiatru, może opierać się na danych meteorologicznych. Jednak stacje meteorologiczne w przeważającej większości są usytuowane w dużych odległościach od siebie, zasłonięte często wysokimi budynkami lub drzewami i brakuje im nowoczesnej aparatury pomiarowej pracującej w sposób ciągły. Wszystko to powoduje, że średnie prędkości wiatru podawane w literaturze dotyczącej klimatu mogą w znacznym stopniu odbiegać od średnich prędkości odpowiadających danej lokalizacji. Ponadto, w klimacie przejściowym jaki znajduje się w Polsce zmiany warunków meteorologicznych pomiędzy kolejnymi latami mogą być znaczące (rys.2). W poszczególnych rejonach Polski średnia prędkość wiatrów może wynosić od $2 \mathrm{~m} / \mathrm{s}$ do nawet $8 \mathrm{~m} / \mathrm{s}$. W związku z tym analizowane wyniki pomiarów powinny być oparte na wieloletnich, standardowo trzyletnich, obserwacjach w miejscu przewidywanej inwestycji. Najkorzystniejsza wysokość do wykonywania pomiarów to wysokość przewidywanej osi wirnika EWi n.p.g..

Korzystanie $\mathrm{z}$ energii wiatru obecnie staje się ważnym sposobem produkcji energii elektrycznej. W tym celu wykorzystuje się elektrownie wiatrowe.

Główne elementy składowe elektrowni wiatrowej to koło wirnikowe z łopatkami oraz generatora, który wytwarza energię elektryczną z energii kinetycznej 
wiatru. Turbina znajduje się na wieży. Elektrownie wiatrowe mogą różnic się mocą, liczbą łopat, czy też osią obrotu (rys.3). Produkcja prądu jest uzależniona od prędkości wiatru. Niektóre elektrownie mogą wytwarzać energię elektryczną już przy prędkości ok. $2 \mathrm{~m} / \mathrm{s}$. Większość osiąga moc nominalną przy ok. $8-12 \mathrm{~m} / \mathrm{s}$ i wyłącza się przy prędkości około $25 \mathrm{~m} / \mathrm{s}$. Wówczas to wysoka prędkość wiatru stanowi niebezpieczeństwo dla obiektu. Energia wiatru zależy od trzeciej potęgi prędkości wiatru.

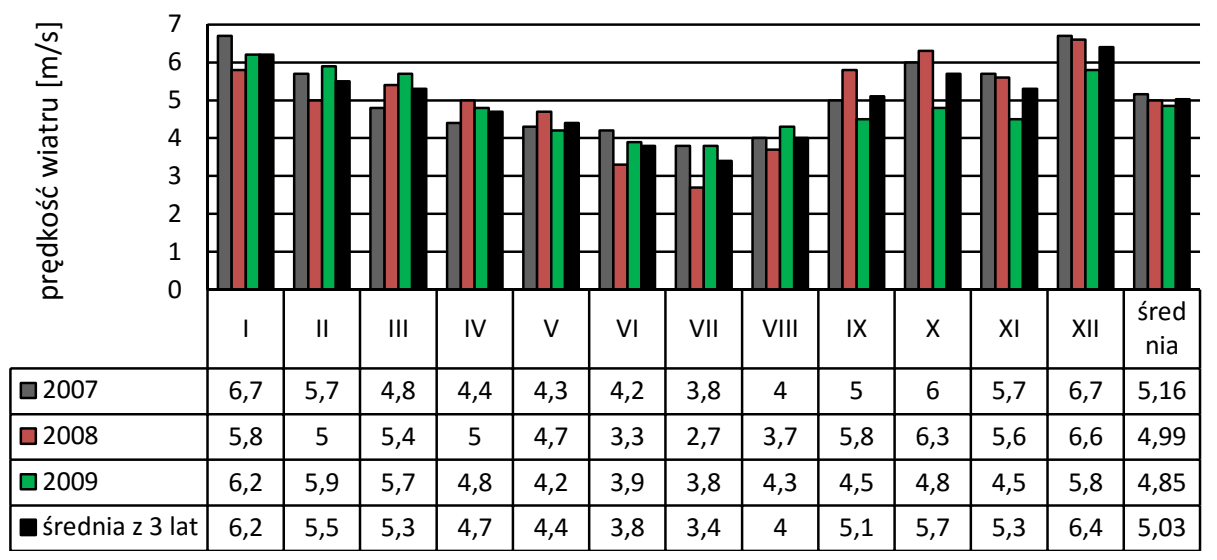

Rys.2. Energia kinetyczna wiatru w trzech kolejnych latach w tej samej miejscowości Podkarpacia [badania własne]

Fig.2. Kinetic energy of the wind for three consecutive years in the same place Podkarpacia [own research]

Zgodnie z prawem Betz'a maksymalna teoretyczna sprawność zamiany energii wiatru na energię mechaniczną wynosi 59,3\%. Sprawność zamiany energii kinetycznej wiatru na energię mechaniczną a następnie na elektryczną nie przekracza $40-50 \%$ i w dużym stopniu zależy od rozwiązań konstrukcyjnych, prędkości wiatru oraz lokalizacji siłowni wiatrowych [3].

\subsection{Energia spadku wód śródlądowych}

Woda jest na Ziemi bardzo rozpowszechniona. Występuje głównie w oceanach, które pokrywają 70,8\% jej powierzchni, ale także w rzekach, jeziorach i w postaci stałej w lodowcach. Część wody znajduje się również pod powierzchnią ziemi, a także w atmosferze (chmury, para wodna). Obecnie energetyka wodna to przede wszystkim elektrownie o dużej mocy, wykorzystujące energię spadku wód śródlądowych. Urządzeniem przetwarzającym energię wody na energię elektryczną są turbiny wodne. Turbina wodna przetwarza energię mechaniczną wody na ruch obrotowy wirnika, który z kolei napędza prądnicę produkując $\mathrm{w}$ ten sposób energię elektryczną. Wykorzystanie w elektrowniach energii wody polega na zredukowaniu w granicach pewnego obszaru (odcinek 
strumienia, rzeki, część zatoki) naturalnych strat energii wody i uzyskaniu jej spiętrzenia względem poziomu odpływu.

Ostatnio coraz większą uwagę poświęca się energetycznemu wykorzystaniu niewielkich cieków wodnych przez budowę tak zwanych małych elektrowni wodnych (rys.3). W pierwszej kolejności dotyczy to tych cieków, na których istnieją już urządzenia piętrzące wykorzystywane do innych celów, np. przeciwpowodziowe.

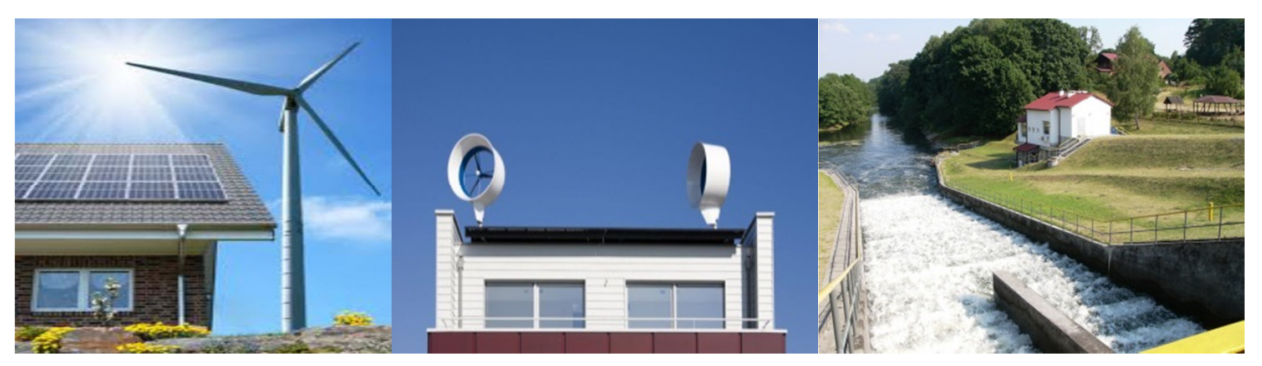

Rys.3. Indywidualne instalacje elektroenergetyczne [4], [5], [6]

Fig.3. Individual power installations [4], [5], [6]

\subsection{Układy kogeneracyjne}

Bardzo popularną i coraz bardziej rozpowszechnioną technologią energetyczną wykorzystywaną w różnej skali mocy, w tym również w gospodarstwach indywidualnych jest kogeneracja, czyli równoczesne wytwarzanie energii elektrycznej i ciepła. Indywidualny układ kogeneracyjny składa się z dwóch podstawowych maszyn: silnika spalinowego i generatora energii elektrycznej napędzanego tym silnikiem. Sprawność przetwarzania energii chemicznej na pracę mechaniczną jest w silnikach spalinowych na poziomie $30-40 \%$. Pozostała energia zawarta w paliwie czyli $60-70 \%$ zamieniana jest na ciepło, które to ciepło można wykorzystać dla celów grzewczych lub technologicznych. Układ kogeneracyjny można zaliczyć do odnawialnych źródeł tylko w przypadku gdy silnik zasilany będzie wyłącznie biopaliwem.

\section{Technologie na etapie badań}

\subsection{Ogniwa paliwowe}

Ogniwo paliwowe jest urządzeniem w którym zachodzi rozbicie w wyniku reakcji chemicznej wodoru ( $\mathrm{w}$ stanie czystym lub jako mieszanina $\mathrm{z}$ innymi gazami) na proton i elektron na anodzie, a następnie na połączeniu substratów reakcji na katodzie. $\mathrm{W}$ wyniku tych reakcji powstaje prąd elektryczny i ciepło. Produktem ubocznym jest woda. Paliwem w ogniwach paliwowych jest wodór, który jest jednym z najbardziej rozpowszechnionych w przyrodzie pierwiastków, 
jednak nie występuje $\mathrm{w}$ przyrodzie $\mathrm{w}$ stanie wolnym a jedynie $\mathrm{w}$ związkach chemicznych, zatem jest wtórnym nośnikiem energii i musi być wytwarzany z wykorzystaniem pierwotnych źródeł energii, takich jak paliwa kopalne, biomasa, energia słoneczna, energia wiatru i wody lub energia reakcji jądrowych. Elektroliza wodoru zapewnia produkcje wodoru o bardzo dużej czystości, jednak wymaga bardzo dużej ilości energii elektrycznej. W chwili obecnej energetyka wodorowa jest znacznie droższa od energetyki konwencjonalnej. Ogniwa paliwowe doskonale nadają się do kogeneracji, czyli jednoczesnej produkcji energii elektrycznej i ciepła dla budynków mieszkalnych.

\subsection{Generatory termoelektryczne}

Generatory termoelektryczne wykorzystują odkryte jeszcze w XIX wieku zjawisko termoelektryczne. Zjawisko to polega na powstawaniu napięcia elektrycznego pomiędzy wolnymi końcami przewodów wykonanych z różnych przewodników w sytuacji gdy pozostałe dwa końce tych przewodów są ze sobą połączone i znajdują się w innej temperaturze niż końce wolne. Powstające napięcie jest wprost proporcjonalne do różnicy temperatur panującej pomiędzy końcami wolnymi a połączonymi (rys.4).

Pomimo wielu prób generatory tego typu nie wyszły poza fazę prototypów ale intensywne prace nad ich wdrożeniem do produkcji trwają. Wielką zaletą tego typu generatorów jest możliwość wykorzystania jako surowca energetycznego ciepła odpadowego lub różnicy temperatur która występuje w różnych procesach technologicznych np. kotle centralnego ogrzewania w stosunku do otoczenia kotła. Aktualnie znacznie bardziej rozpowszechnione jest wykorzystanie zjawiska odwrotnego do termoelektrycznego, to znaczy wytworzenie różnicy temperatur pomiędzy końcami przewodów przez przykładanie do wolnych końców przewodników napięcia i powodowanie przepływu prądu. Następstwem tego jest wytworzenie różnicy temperatur pomiędzy zasilanymi napięciem a połączonymi ze sobą końcami przewodów.

\subsection{Generatory piezoelektryczne}

Generatory piezoelektryczne wykorzystują zjawisko piezoelektryczne polegające na pojawieniu się na przeciwległych powierzchniach kryształów ładunków elektrycznych przeciwnego znaku, gdy kryształ znajduje się pod działaniem sił mechanicznych które go ściskają (rys.5). Generatory tego typu już pracują jednak ich charakterystyki dynamiczne, tzn. zależność pomiędzy przebiegiem czasowym przyłożonych sił a przebiegiem procesu produkcji energii elektrycznej czyni proces sterowania produkcją energii trudnym i kosztownym. $Z$ tego powodu generatory piezoelektryczne nie są rozpowszechnione. Zjawisko piezoelektryczne powszechnie wykorzystywane jest tylko w zapalniczkach, zabawkach, gdzie wytwarzana energia może mieć charakter impulsowy. 


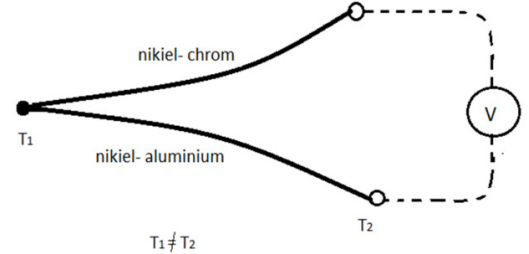

Rys.4. Efekt termoelektryczny

Fig.4. Thermoelectric effect

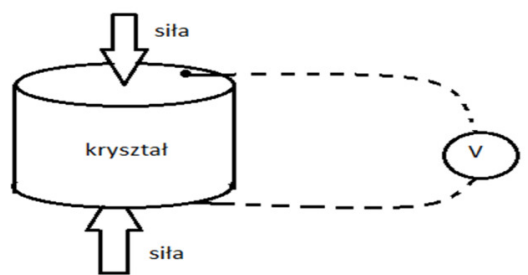

Rys.5. Efekt piezoelektryczny

Fig.5. Piezoelectric effec

\section{Produkcja energii elektrycznej w przypadku odsprzedaży do krajowego systemu elektroenergetycznego}

Krajowy system elektroenergetyczny charakteryzuje się sinusoidalnym przebiegiem wytwarzanych napięć, stałą wartością częstotliwości, stabilizowanym napięciem które może się zmieniać tylko w ściśle ograniczonym przedziale oraz kolejnością faz (w zakładach energetyki zawodowej napięcie wytwarzane jest jako trójfazowe z fazami przesuniętymi o 120 stopni). W tej sytuacji producent energii elektrycznej musi ściśle dopasować parametry wytwarzanych napięć do tych, które panują w krajowym systemie elektroenergetycznym (rys.6). Jeżeli produkuje napięcie stałe, to musi je zamienić na sinusoidalne przy pomocy falownika.

Jeżeli produkuje sinusoidalne, musi dopasować częstotliwość do częstotliwości systemu przy pomocy przetwornicy częstotliwości. Jeżeli wytwarza napięcie o innej wartości niż w systemie musi je transformować przy pomocy transformatorów. Gdy wszystkie parametry wytwórca ma dopasowane do panujących w systemie musi być jeszcze wykonana synchronizacja, to znaczy zgodność fazowa napięć oraz kolejność faz jeśli produkowane napięcia są trójfazowe.
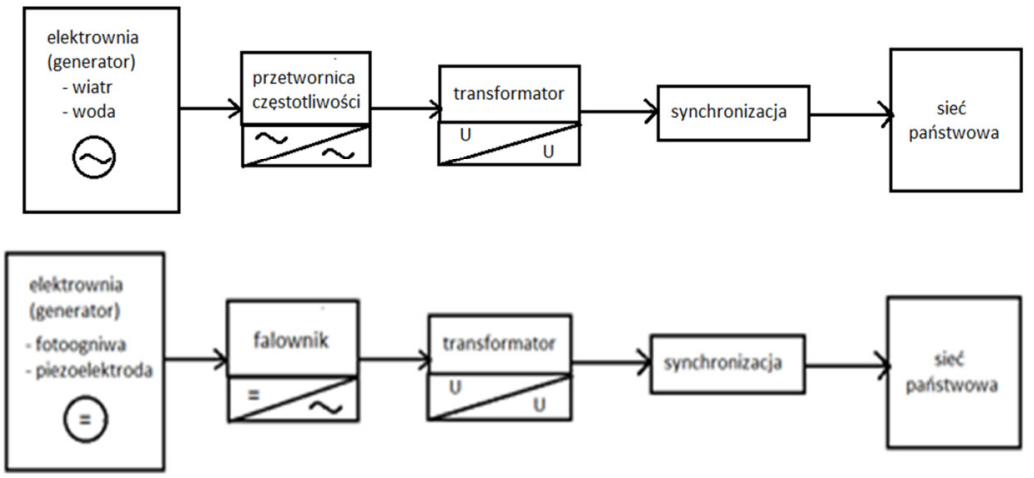

Rys.6. Schematy urządzeń zapewniających dopasowanie indywidualnego producenta energii elektrycznej do krajowego systemu elektroenergetycznego

Fig.6. Circuit devices provide matching individual producer of electricity to the national power system 


\section{Podsumowanie}

Do końca 2020 roku nowo oddawane do użytku budynki w krajach UE będą musiały przestrzegać bardzo ścisłych norm $\mathrm{w}$ zakresie oszczędności energii. Zgodnie $\mathrm{z}$ nowymi wytycznymi budownictwo mieszkaniowe powinno praktycznie nie emitować gazów cieplarnianych, natomiast energia, która będzie im niezbędna, powinna $\mathrm{w}$ znaczącej części pochodzić z odnawialnych źródeł. Może to być jeden z czynników motywujący inwestorów indywidualnych do rozpoczęcia produkcji energii elektrycznej na mikro skalę. Inną przesłanką może być potencjalne zmniejszenie kosztów utrzymania domu, a w przypadku sprzedaży energii elektrycznej do sieci, zapewnienie dodatkowego źródła dochodu. Warto przy tym wspomnieć, że wraz z rosnącym globalnym popytem na mikroinstalacje ich ceny będą stale spadać.

\section{Literatura}

[1] Pluta Z.: Podstawy teoretyczne fototermicznej konwersji energii słonecznej, Oficyna Wydawnicza Politechniki Warszawskiej, Warszawa 2000.

[2] Klugmann- Radziemska E.: Fotowoltaika w teorii i praktyce, Wydawnictwo BTC, Legionowo 2010.

[3] Gumuła S, Knap T, Strzelczyk P, Szczerba Z.: Energetyka wiatrowa, Uczelniane Wydawnictwo Naukowo-Techniczne AGH, Kraków 2006.

[4] http://fachowabudowa.pl/wlasna-elektrownia-wiatrowa/ \{dostęp: 31 marca 2013\}.

[5] http://gospodarka.dziennik.pl/twoje-finanse/artykuly/490213,domowa-elektrowniawiatrowa-koszty-instalacji-oszczednosc-na-pradzie.html dostęp:12.05.2015\}.

[6] http://rzgw.gda.pl/cms/fck/uploaded/IPR/Mylof\%20na\%20stron\%C4\%99\%2007153 508.jpg \{dostęp:11.03.2015\}.

\section{PROSUMER ENERGY IN SCATTERED BUILDINGS}

\section{S u m m a r y}

The idea of prosumer energy is a combination of two processes in one building. The process of energy consumption and production. In this case, energy consumption means the use of energy produced by its manufacturer, and possibly supplementing its energy needs by using energy from the national grid. Energy production means here producing it in excess of its own needs in order to sell it to the national electricity system. However, it's the technologies based on renewable raw materials that deserve the producers' particular attention, as the price of buying energy from these sources is much higher than the one derived from fossil fuels. Presented work shows the characteristics of electricity generating technologies, both those already developed and available and those that are in the research phase with the prospect of implementation in the unspecified future.

Keywords: scattered energy sources, electricity production, producer's cooperation with the national electricity system

DOI:10.7862/rb.2016.226

Przestano do redakcji: 10.07.2016 $r$.

Przyjęto do druku: $30.11 .2016 r$. 